\title{
PEMAKAIAN ASAM ASKORBAT UNTUK PRODUKSI KOENZIM QUINONE DENGAN INDUKSI SEL NICOTIANA TABACCUM
}

\author{
Said Nurdin dan Afnizar Huzaimi
}

\begin{abstract}
ABSTRAK
Koenzim quinone merupakan produk intrasellular nicotiana tabaccum, sehingga untuk mengisolasikannya diperlukan penambahan antioksidan. Penelitian penambahan antioksidan berupa asam askorbat dengan variasi konentrasi bertujuan menyelidiki tingkat efektivitas pemakaian senyawa tersebut dengan proses induksi sel. menurut perubahan waktu. Proses induksi berlangsung melalui penanaman inokulum kedalam nutrien sampai terbentuknya callus. Callus dipindahkan kedalam media pemeliharaan yang telah diberikan nutrien, sehingga tumbuh dan berkembang menjadi sel baru. Pertumbuhan sel dalam medium cair diamati melalui berat sel segar yang diperoleh. Perkembangan berat sel segar dan produksi koenzim quinone kasar pada berbagai konsentrasi vitamin C tersebut ditentukan dengan menggunakan HPLC dan pendeteksiannya dipakai spektrofotometer Shimadzu SPD-10 A pada panjang gelombang 275 $\mathrm{nm}$. Hasil pembentukan koenzim quinone diuji pada hari ke-1; 3; 5; 6 dan 7 dengan konsentrasi $0,5 \mathrm{mg} / \mathrm{l}$. Nilai optimalnya dicapai sebesar $0,3598 \mathrm{ppm} ; 0,3641 \mathrm{ppm} ; 0,3675 \mathrm{ppm} ; 0,3699 \mathrm{ppm}$ dan $0,3718 \mathrm{ppm}$, dan pada konesentrasi asam askorbat $=0,7 \mathrm{mg} / \mathrm{l}$ menunjukkan produksi koenzim quinone sebanyak 0,3920 ppm;0,3791 ppm;0,3996 ppm;0,4005 ppm dan 0,4030 ppm.
\end{abstract}

Kata kunci : asam askorbat, antioksidan, coenzim quinone, induksi sel, nicotiana tabaccum, inokulum, nutrien, callus, medium

\section{PENDAHULUAN}

Produksi metabolit sekunder melalui induksi sel tumbuhan kini berkembang pesat. Induksi sel tembakau dengan asam askorbat sebagai antioksidan menghasilkan enzim quinone. Enzim quinone ini juga dapat dihasilkan dari sel tumbuhan yang lain, seperti daucus corata, lypersicum escelentum, lactuca scariola dan datura tatula. Jenis bakteri petromonas eksterquens juga merupakan penghasil enzim (Urakami dan Okubo, 1988). Koenzim quinone kasar (crude coenzym quinone) dideteksi melalui pengenalan sifat-sifat fisik dan kimia. Sifat fisik menunjukkan bau yang tajam dan memedihkan mata, sedangkan karakteristik kimianya bersifat oksidator yang dapat direduksi menjadi hydroquinone. Produksi enzim quinon melalui induksi sel pada bebagai konsentrasi asam askorbat mengacu pada pertambahan total massa sel. Bila sel tumbuhan diinokulasikan dalam suatu media, maka akan terjadi suatu kenaikan jumlah sel yang cepat. Kenaikan ini disebabkan oleh pembelahan sel secara binair melintang dan terjadi pada semua sel yang sedang tumbuh aktif. Pembelahan ini berlangsung setelah dinding sel melintang, sehingga satu sel tunggal membelah menjadi dua sel baru. Setiap sel baru dapat mengulangi lagi proses tersebut (Shuler dan Kargi, 1992). Kultur sel jaringan dan tumbuhan yang menghasilkan enzim akan ekonomis tergantung beberapa faktor: nilai jual produk, volume pasar, laju pertumbuhan kultur dan perolehan produk. Perolehan produk ini juga dipengaruhi lingkungan, kinetika, bioreaktor, rheologi dan perpindahan massa. Perpindahan massa yang disebabkan oleh peristiwa aerasi juga merupakan aspek penting dalam kultivasi sel daun tembakau. Hubungan antara pertumbuhan sel agrobacterium dengan kandungan intrasellular quinone adalah dikendalikan oleh penyediaan oksigen (Kuratsu, 1984; Ho dkk, 1995). Peningkatan jumlah oksigen mengakibatkan pertumbuhan sel semakin cepat, akan tetapi produk yang diinginkan belum tentu bertambah. Oleh karena itu, penambahan vitamin $C$ tersebut berfungsi untuk memecahkan dinding sel, karena enzim ubiquinone merupakan produk intraselluler, sehingga dinding selnya harus dihancurkan untuk mengeluarkannya. Pengeluaran sel yang membentuk enzim ini pernah dilakukan dengan memvariasikan 
pengadukan. Pengadukan divariasikan terhadap berat sel basah dan produk kandungan quinone berkisar antara 140 - $170 \mathrm{rpm}$, dan berlangsung pada suhu kamar. Hasilnya menunjukkan suatu pertambahan berat sel dan konsentrasi crude quinone mencapai 0,275 ppm pada kecepatan putaran $160 \mathrm{rpm}$ (Nurdin dan Huzaimi, 1998). Penelitian berikutnya dikerjakan dengan melihat efek temperatur terhadap pembentukan enzim. Pembentukan enzim dan berat sel basah dilukiskan kurvanya beriringan dengan tahapan pertumbuhan sel. Pertumbuhan sel dan perolehan koenzim quinone maksimum rata-rata terjadi pada batasan temperatur $25-35{ }^{\circ} \mathrm{C}$, dan nilai enzim yang diperoleh berlandaskan pada waktu observasi. Observasi dilakukan berturut-turut hari ke-5; 10; 15; 20; 25, 30 dan 35 memperlihatkan quinone optimal yang diraihnya berada pada kisaran 0, $2471-0,2593$ ppm; 0,2511 - 0,2611 ppm; 0,2574 - 0,2799 ppm; 0,2750 - 0,2755 ppm; 0,2611 - 0,2711 ppm; 0,2531 $0,2592 \mathrm{ppm}$ dan 0,2493 - 0,2599 ppm (Nurdin dan Huzaimi, 1999). Nilai konsentrasi yang diraih ini telah memberikan kondisi temperatur optimal, tetapi investigasi lanjutan untuk peningkatan produksi sedang dan masih terus diujicobakan. Pengujian penggunaan asam askorbat sebagai antioksidan ini berlandaskan sifat fisiknya berbentuk kristal, titik leleh 190 - $192{ }^{\circ} \mathrm{C}$ dan mudah larut dalam air, sedangkan sifat kimianya berupa asam, reduktor dan mudah teroksidir di udara dalam bentuk larutan (Orthmer, 1986). Antioksidan juga mempengaruhi proses dialisis sel, sehingga terjadinya peningkatan produksi enzim (Kuratsu, 1984). Dalam hubungan inilah, maka dicoba investigasi lanjutan tentang kondisi proses peningkatan produksi enzim dari berbagai konsentrasi penambahan asam askorbat sebagai antioksidan.

Penelitian ini bermaksud menginvestigasi tingkat efektivitas pemakaian antioksidan pada kultivasi sel nicotiana tabaccum dengan variasi konsentrasi dan perubahan waktu. Hal.ini diprediksikan bila adanya suatu peningkatan hasil kadar enzim, berarti teknologi induksi dengan penambahan antioksidan dapat diajukan untuk pemurnian dan penyelidikan lanjutan, sehingga enzim ini berdayaguna dalam berbagai industri, seperti farmasi dan bahan makanan sebagai pembuatan zat warna. Pemanfaatan hasil penelitian ini akan berguna sebagai bahan usulan konsiderasi pemilihan tingkat pemakaian konsentrasi asam askorbat pada induksi sel nicotiana tabaccum untuk produksi quinone, dan diharapkan nantinya dapat menjadi suatu bahan studi penelaahan kemungkinan pengurangan impor quinone, serta adanya suatu peningkatan pemberdayaan sumber daya alam tembakau, sehingga pemakaiannya tidak hanya sebagai daun pembungkus dan komoditi ekspor.

\section{METODE PENELITIAN}

Metode penelitian pemakaian asam askorbat terhadap produksi quinone dengan induksi sel daun tembakau meliputi tahapan-tahapan : persiapan alat, bahan dan prosedur kerja. Urutan prosedur kerja adalah sbb (Lee, 1991):

Nicotiana tabaccum sebagai sumber sel diperoleh dari kawasan penanaman tembakau rakyat Takengon -Aceh Tengah - D.I. Aceh. Eksperimen dilakukan dengan menggunakan daun tembakau yang masih segar dan dibersihkan dari kotoran melalui pencucian. Sampel tersebut dipotong-potong berukuran $1 \mathrm{~cm} \times 1 \mathrm{~cm}$ dan ditempatkan dalam beaker glass yang telah disterilkan dengan ethanol $80 \%$. Penumbuhan inokulum pada medium padat digunakan $30 \mathrm{~g}$ sukrosa, $1 \mathrm{mg}$ thiamine $\mathrm{HCl}, 100 \mathrm{mg}$ myoinositol dan $0,2 \mathrm{mg}$ dichlorophenoxyacetic acid. Semua bahan ini dicampur dan dikontrol pHnya $=6$ melalui penambahan $0,5 \mathrm{~N} \mathrm{NaOH}$. Campuran ini diambil sebanyak $8 \%$ dan dimasukkan kedalam cawan petri. Daun tembakau yang telah disterilkan disusun diatas cawan tersebut dan ditutup serta dibalut dengan alumanium foli, kemudian dipanaskan dalam autoclave selama 15 menit pada temperatur $115^{\circ} \mathrm{C}$ dan dimasukkan ke-dalam clean bench. Selama 7 hari diamati pertumbuhan sel pada pinggir daun tembakau. Sel baru ini dipisahkan dan ditumbuhkan lagi pada medium padat baru, selanjutnya sel baru tersebut diambil dan dikembangkan pada medium cair. Perlakuan ini dilakukan berulang kali setiap adanya pertumbuhan sel (Andrew dan Unno, 1992). Selanjutnya, proses penginduksian sel dikerjakan dalam $300 \mathrm{ml}$ erlemeyer sebanyak 7 buah. Erlemeyer tersebut ditempatkan pada orbital shaker selama 7 hari dan analisisnya dimulai hari ke-1 sampai hari ke 7 dengan variasi asam askorbat sebagai antioksidan pada interval $0,1-0,9 \mathrm{mg} / \mathrm{l}$. Analisis hasil proses mencakup sel segar dan kandungan quinone. Pekerjaan ini dimaksudkan untuk mengetahui perkembangannya selama proses berlangsung, dan dilakukan dengan penimbangan kertas saring. $25 \mathrm{ml}$ sampel perolehan tersebut difilter, dan kertas saringnya dikeringkan dengan pompa vakum. Berat sel segar ditimbang dan filtratnya yang diperkirakan mengandung koenzim quinone dianalisis dengan HPLC (High Performance Liquid Chromatography) Shimadzu LC-1045. Enzim ini dideteksi dengan spektrofotometer Shimadzu SPD-10 A pada panjang gelombang $275 \mathrm{~nm}$. Pengolahan data hasil penelitian dan analisisnya dilakukan secara grafis menggunakan program Microcal Origin - Version 4.1 


\section{HASIL DAN PEMBAHASAN}

Hasil yang diperoleh dari induksi sel nicotiana tabaccum didiskusikan menurut urutan pertumbuhan sel dan pemakaian asam askorbat terhadap produksi koenzim quinone. Pengaruh pengujian penambahan antioksidan asam askorbat terhadap pertumbuhan sel diperlihatkan menurut gambar 1 berikut:

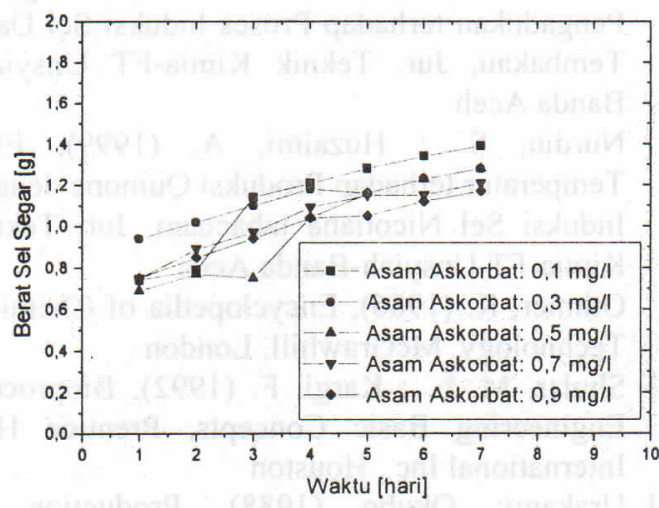

Gambar 1 Berat sel basah dengan variasi asam askorbat menurut perubahan waktu

Gambar 1 menunjukkan kenaikan pertumbuhan sel seiring dengan peningkatan waktu, tetapi perkembangannya menurun bila asam askorbat yang terpakai meningkat. Hal ini diperkirakan karena konsentrasi asam askorbat yang ditambahkan kedalam media pemeliharaan bereaksi dengan oksigen, sehingga laju absorbsi oksigen oleh sel untuk perkembang biakannya mengalami penurunan (Ikeda, 1976). Sebaliknya, pertumbuhan sel berlangsung baik.pada konsentrasi antioksidan rendah, gejala ini diperkirakan karena kelarutan oksigen pada konsentrasi tersebut tidak terganggu.

Variasi penambahan asam askorbat terhadap pembentukan koenzim quinone diperlihatkan gambar 2 berikut:

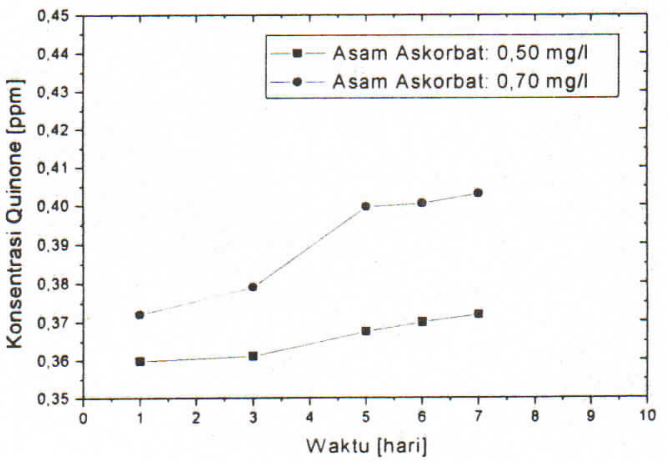

Gambar 2 Pembetukan koenzim quinone dengan variasi asam askorbatmenurut perubahan waktu.
Kurva 2 memperlihatkan peningkatan pembentukan quinone bila konsentrasi asam askorbat meningkat. Kondisi ini diprediksikan karena oksigen yang diabsorbsi oleh medium terlebih dahulu bereaksi dengan asam askorbat, sehingga makin banyak penambahan vitamin tersebut menyebabkan ketersediaan oksigen berkurang, dan akhirnya mengganggu metabolisma dan perkembangan sel (Ikeda, 1976). Pertumbuhan sel untuk produksi quinone memerlukan oksigen, tetapi bila oksigen tersedia dalam medium cukup tinggi, maka membran atau dinding sel akan terbentuk dengan sempurna. Kesempurnaan dinding sel mengakibatkan kerendahan permeabilitas terhadap koenzim quinone, sehingga enzim yang terbentuk mengalami kesulitan ekskresi keluar melalui dinding sel. Sebaliknya, jika konsentrasi oksigen didalam medium dibatasi sampai tingkat suboptimum (dibawah kesempurnaan pembentukan dinding sel ), maka dinding sel mempunyai permeabilitas tinggi terhadap koenzim quinone. Ketinggian permeabilitas tersebut menyebabkan kemudahan koenzim quinone mengalami ekskresi keluar sel (Ikeda, 1981). Hal inilah mendasari pengujian quinone dilakukan hanya terhadap pemilihan penambahan asam askorbat sebanyak 0,5 dan $0,7 \mathrm{mg} / 1$.

\section{KESIMPULAN DAN SARAN}

Penyelidikan pemakaian asam askorbat pada kultivasi sel nicotiana tabaccum terhadap produksi koenzim quinone telah memberikan kondisi tingkat penggunaannya berbeda-beda. Hal ini dapat dilihat dengan hasil pembentukan sel segar dan produksi enzim pada berbagai konsentrasi. Pertumbuhan sel seiring dengan peningkatan waktu, tetapi perkembangannya menurun bila asam askorbat yang terpakai meningkat. Penambahan asam askorbat pada konsentrasi $0,5 \mathrm{mg} / \mathrm{l}$ dan $0,7 \mathrm{mg} / \mathrm{l}$ diinvestigasikan pembentukan quinone menurut waktu pengamatan. Pengamatan yang dilakukan berturut-turut hari ke-1; 3; 5; 6 dan 7 pada konsentrasi $0,5 \mathrm{mg} / \mathrm{l}$ membentuk koenzim quinone masing-masing sebesar $0,3598 \mathrm{ppm} ; 0,3641 \mathrm{ppm}$; $0,3675 \mathrm{ppm} ; 0,3699 \mathrm{ppm}$ dan $0,3718 \mathrm{ppm}$, sedangkan pemberian asam askorbat sebanyak 0,7 $\mathrm{mg} / \mathrm{l}$ menunjukkan produksi quinone berturut-turut 0,3920 ppm; $0,3791 \mathrm{ppm} ; 0,3996 \mathrm{ppm} ; 0,4005 \mathrm{ppm}$ dan $0,4030 \mathrm{ppm}$.

Penelitian lanjutan untuk peningkatan hasil kadar koenzim quinone dapat diusulkann dengan melihat pengaruh sinar ultra violet dan immobilisasi melalui gambas kering. 


\section{UCAPAN TERIMA KASIH}

Ucapan terima kasih disampaikan kepada pengelola proyek pengkajian dan penelitian ilmu pengetahuan dasar Ditbinlitabmas-Ditjen Dikti-Depdiknas yang telah bersedia mendukung finansial, dan Lembaga Penelitian Unsyiah yang telah memfasilitasinya beserta pihak lainnya yang terlibat langsung maupun tidak langsung dalam pelaksanaan riset.

\section{DAFTAR PUSTAKA}

[1] Andrew, A. ; Unno, H. (1992), Cultivation of Tobacco Cell Culture, Tokyo Institute of Technology, Tokyo

[2] Ikeda, T. (1976), Formation of Ubiquinone by Tobacco Plant Cell and Suspension Culture, Agricultural Biological Chemistry, Vol. 15, p. $568-569$

[3] Ikeda, T. (1981), Selection of Cultured Tobacco Cell Strains Producing High Level of Ubiquinone 10 by a Cell Cloning Technique, Agr. Bio. Chem., Vol. 45 (7), p. 1627 - 1633

[4] Ho; Kelly; Gregory (1995), Cell Damage and Oxygen Mass Transfer during Cultivation of Nicotiana tabaccum in Stirred Tank Bioreactor, Biotechnology Progress, Vol. 11, Nr. 2
[5] Kuratsu, Y. (1984), Aeration and Agitation Effect on Coenzim Q10 Production by Agrobacterium species, J. Ferment. Technol., Vol. 62 , Nr. 3

[6] Lee, J. M. (1991), Biochemical Engineering, Prentice Hall International Inc, Englewood Cliffs, New Jersey

[7] Nurdin, S. ; Huzaimi, A. (1998), Pengaruh Pengadukan terhadap Proses Induksi Sel Daun Tembakau, Jur. Teknik Kimia-FT UnsyiahBanda Aceh

[8] Nurdin, , S. ; Huzaimi, A. (1999), Efek Temperatur terhadap Produksi Quinone dengan Induksi Sel Nicotiana tabaccum, Jur. Teknik Kimia-FT Unsyiah-Banda Aceh

[9] Othmer, K. (1986), Encyclopedia of Chemical Technology, McGrawhill, London

[10] Shuler, M. L. ; Kargi, F. (1992), Bioprocess Engineering Basic Concepts, Prentice Hall International Inc., Houston

[11] Urakami; Okubo (1988), Production of Iseprenoid Compound in The Facultativ metylotrop petromonas exterquens, J. Ferment. Technol. , Vol. 62, Nr. 3 